\title{
Music and Identity: A Study on Raden Mas Celleng Community
}

\author{
F RahmawatI \\ Institut Agama Islam Negeri (IAIN) Madura, Indonesia \\ \{fithriyah@iainmadura.ac.id\}
}

\begin{abstract}
Sanggar Seni Budaya dan Religi Raden Mas Celleng (RMC Community) Pamekasan is a community which has been established to respect the indigenous and religious musical arts. Many programs have been developed to maintain the cultural heritage as well as to deliver Islamic values within societies. One of the programs is establishing a workshop of both traditional and Islamic musical arts. The groups that have been created are Musik Daul Percussion Mas Celleng, Hadrah Albanjari Al Jamil, and Musical Collaboration. Meanwhile, the members of this community come from various ages, gender, and occupation. However, the majority of them are young people aged 12-25 years old. The present study was carried out with an ethnographic design which aims at portraying the community, especially with regard to the roles of Sanggar Seni Budaya dan Religi Raden Mas Celleng in terms of preserving the cultural heritage as well as expressing the identity of Islam among the youth. As a qualitative design, the data was mainly gathered by conducting observation, interviews and analyzing document. The finding reveals the positive views regarding to what extent Sanggar Seni dan Budaya RMC establishes the cultural heritage, explores the youth's talents as well as presents the values of Islam. Most importantly, identity expression of youth and Islamic moderation was also noticed.
\end{abstract}

Keywords: Islamic Identity, Music, Youth

\section{Introduction}

Indonesia is a country in which diversity is commonly found in many ways, including culture and religion. Different area may have different traditions, norms, and habits. Consequently, it is not surprising that many groups or communities, taking cultural and religious themes, have been present in societies thank to the diversity. These communities transfer values and principles on a regular basis into their communities. The way of life of a particular community is reflected through arts and local tradition. In other words, arts and tradition are regarded a medium for people to express their perspectives and identities as well as to inspire the people's life at the spiritual, moral and social levels [1].

There is no doubt that culture and Islam, as well as the relationship between them, would be a never ended discussion. For some considerations, many people claimed that Islam and culture are two contrastive issues. In other words, they would never be able to stand harmoniously. It seems to be true since in some cases culture appears to be more powerful than religion, and vice versa. Therefore, it leads to resistance [1]. However, this claim is not necessarily true. In a particular context, the interaction of religion and culture can stand together without any conflicts. Indeed, the harmony of culture and religion is like a mutual relationship.

One thing needs to be paid attention in this era is the decreasing of indigenous culture within societies. It is not surprising, however, that the emergence of technology and the unavoidable effect of globalization may lead to this marginalization. Believe or not, the western culture is reputed to be more relevant with youth generation because it brings about modernization. Meanwhile, the local traditions are regarded to be old-fashioned. Moreover, sometimes friction between culture and organized religion occurs. Most importantly, a little attention on preservation and development of local cultures is considered as one of the factors influencing the existence of 
the culture in societies. Therefore, this is regarded as an internal factor of marginalization of the local wisdom in societies [1].

Besides, it is quite often that some people attribute everything related to tradition (the traditional) as kampungan (old-fashioned; out of date). This condition has attracted the attention from some people who are concerned about the traditions in Madura. They realize that if they do not maintain their cultures and everything related to their local traditions, they are going to lose them. For this reason, they established a community named Sanggar Seni Budaya dan Religi Raden Mas Celleng (RMC Community) in oder to preserve their local traditions, especially music arts. The RMC Community has a great hope to bring an up-to-date version of their traditions that have been regarded out of date in societies.

Arts, musical arts in particular, nevertheless, is still a controversial issue in Islam up to the recent times. Amnon Shiloah, a musicology expert, as quoated in Rasmussen (2019), stated that a never-ending debate on the legality of music has taken place since the first century of Islam in Arabian peninsula. Undoubtfully, musical arts and Islam seemed to be a dichotomic issue. According to the orthodox view, Islam and music are not compatible. In line with this, it was often said that music is haram (religiously forbidden). People are prohibited to perform or perceive any kind of music or rhythm. Even, when a various kind of musical instruments are created, the debate on musical performance has expanded to a controversy on selling them. Moreover, the debate includes also the aspects of the restriction applied. Many believe that performing as well as listening to religious or Islamic music is allowed for Muslims. The majority of ulama agree that musical performance is haram if it deflects people from remembering Allah (dzikrullah). In contrast, music is acceptable if it leads to goodness. It refers to what people usually say as religious music (seni Islami/ religi, musik Islami)[2]. Similarly, Shihab [3] said that:

"Seni adalah keindahan. Ia dapat tampil dalam beragam bentuk dan cara. Apa pun bentuk dan caranya, selama arah yang ditujunya mengantar manusia ke nilai-nilai luhur, maka ia adalah seni Islami. Karena itu, Islam dapat menerima aneka ekspresi keindahan selama tidak bertentangan dengan nilai-nilai al-Khair dan al-Ma'ruf, yakni nilai-nilai universal yang diajarkan Islam serta nilai lokal dan temporal yang sejalan dengan budaya masyarakat selama tidak bertentangan dengan al-Khair tersebut".

Al-Qardawi [4] mentioned that there are two opinions on the allowance of playing and listening to music. The first is mostly driven by a textual interpretation of religious doctrine. According to this opinion, music is haram. The second opinion is more based on logical consideration in which playing and listening to music is considered halal. Musical arts is allowed in Islam as long as it leads to al-khair. For those who belong to this opinion, music can be an integral part of dakwah.

In the discussion of religious music, the term 'music' is mostly identified as instrumental music or songs accompanied by music [5]. In Indonesia, the term 'Islamic musical arts' is so popular. Rasmussen (2019) identified this term as "musik bernapaskan Islam, musik rohani, musik bernuansa Islam, atau musik Islami saja". In line with the genre of Islamic music, Rasmussen (2019) has divided it into three major genres, i.e. Islamic musical arts adopting the Arabian (Middle Eastern) performance and particularly using Arabic language; Islamic music derived from the Indonesia's indigenous culture, and Islamic music collaborated with western contemporary music. It is said that Islamic music or songs do not need to be delivered in Arabic (the language of Alquran). It is because not all Arabic songs are containing Islamic values in their messages, lyrics, and performance. While the western songs can be an expression of beauty as long as they reflect Islamic values.

Pamekasan is a regency in Madura in which the slogan of Gerbang Salam/Gerakan Pembangunan masyarakat Islami (The movement of Islamic society development) is widely wellreceived. It refers to the local government regulation according to aqidah, sharia, and morality [6]. With the cultural richness of traditional music in Pamekasan, it is worthy to explore the existence of RMC Community and its role in the region. It is particularly interesting to see how RMC community has integrated Islamic music and local traditions into modernity. Most importantly, since many scholars have noticed that music can be utilized as an expression of identity [7], the concept of identity expression among the youth is used in this article. 


\section{Method}

This study used a qualitative approach to explore the contribution of RMC Community in building and characterizing Islamic identity among the Muslim youth in the neighborhood. A qualitative inquiry seeks to understand and interpret human and social behaviors as practiced by participants in a particular social setting [8, p. 420]. In addition, an ethnographic design is applied in this study to describe, analyze, and interpret the learned patterns of values and behaviors of the culture sharing group, i.e. the RMC community. As a qualitative research, participants and settings [8], are selected in this study. Therefore, RMC Community is choosen as the subject of the research as well as the culture sharing group where the chairs and the members were the participants of the study. The cultural theme being observed in this study is Islamic identity and modernization brought by RMC Community.

Since a qualitative inquiry is applied, the researcher is the key instrument in gathering the data through various instruments, namely observation, documentation and interviews. This study is carried out within an ethographic design in which the researcher becomes an observer participant who positioned herself by describing her involvement in the community and her role as an observer of the group [9]. Documentation refers to obtaining any documents or pictures related to the existence of RMC and its programs. Whereas, interviews were conducted in an attempt to gain an in-indept understanding and personal perspectives about the RMC and its roles in societies as well as to reveal the perception of the members of RMC and the people in the surrounding. Observation has been carried out since the very first time the community has been established. The data was gathered from various ways after which the researcher presented, reduced, analyzed, then interpreted it.

\section{Result and Discussion}

In this section, the description of RMC Community is presented earlier to figure out how the community was established, what are the objectives and the programs that have been carried out. As mentioned earlier, RMC Community is a community which has been living and developing in Pamekasan Regency, Madura, East Java. The RMC Community becomes an umbrella for mostly musicians in Pamekasan and those who concern about cultures and musics adhering to Islamic messages and nuance. The members of RMC come from various ages, gender, and occupation. Indeed, the majority of members are teenagers aged between 12-25 years-old. The primary concern of this community is to preserve the cultural musical heritage of Indonesia in general and Madurese cultures in particular as well to affix Islamic values in the entire programs. Although this community conducted the first program in 2012, it was officially established later in 2014.

The major program of RMC is conducting regularly workshop on traditional and Islamic music for the members in particular and the society in general. It is interesting to see that the members are not true musicians. The majority of them are joining the RMC with no musical competence but with a big passion to become musicians. After participating the weekly workshops and rehearsals, they are confident enough to get involved in a musical performance. The community has established a number of musical groups order to achieve the goals. One of the groups is Musik Daul Mas Celleng.Musik daul (some Madureses sayul-daul), which is a contemporary music percussion of Madura and is originally an innovated version of tongtong instruments. The term tongtong (kentongan) is derived from the sound of a drum made from bamboo or wood. Combined harmoniously with other instruments such as kenong, gendang, dung-dung, dug-dug, bung-bung, kalenang, gong, terbhang/ rebana and unused drums of differenet sizes, it produces dynamic sound and rhythm which is beautiful to listen to.

There is no record where and when $u l$-daul has been first developed. Moreover, each district or community in Madura has its own style and characteristics of $u l$-daul in terms of the instruments or the music arrangement, depending on the creativity of each community. Traditionally, the music of $u l$-daul is usually accompanied by Madurese indigenous songs. However, RMC community came up with its distinctive characteristics by taking Islamic or religious songs such as shalawat.

Samroh Al Mawaddah and Hadrah Albanjari Al Jamil are two other groups that have been established. The two groups have a common characteristics in the sense that they are using rebana 
as the instruments (although it is not identically the same) and they perform with a number of people within one group. Terbhang/ rebana is classified as a membrane musical instrument since its sound comes from the membrane (leather) stretched on the circle frame made from wood [1]. Meanwhile, the membrane instruments are various and it is named according to the shape, type, and size, namely jedor, bedug, genjring, gendang, kenthing, kentung and ketipung. It has been assumed that rebana in Indonesia was firstly introduced by the Arab traders through the maritime route. Therefore, it is typically regarded as musical instruments from the Middle East and as a part of Islamic culture. Another reference stated that terbhang/ rebana was firstly mentioned in a smaradahana wedding, 1135 AD (Kunst as cited in Bouvier [10]. However, another hypothesis mentioned that terbhang and rebana originated from non-Muslims in Sri Lanka.

However, there are some distinctive features between samroh and hadrah. Samroh traditionally refers to musical arts carried out by women, while hadrah albanjari can be performed by either women or men. In RMC Community, the members of Samroh Al Mawaddah are women aged between 17-40 years old. On the other hand, the members of Al Jamil are young men aged between 12-25 years old, who are mostly students of a junior and senior high school and a university. Another feature that makes them distinctive is the music arrangement. Both samroh and hadrah have its own beat. Most importantly, if qasidah song is customarily delivered within samroh, shalawat is usually carried out within hadrah albanjari. However, it is possible that samroh uses shalawat in the performance.

Finally, the latest group that has been promoted is a collaboration between modern and traditional music. This collaboration lies in a musical arrangement in which modern musical instruments such as a keyboard, drum, guitar, bass, and others are combined with traditional instruments (as in $u l$-daul). This collaboration is inspired by the performance of Kiai Kanjeng, a group music led by Emha Ainun Najib. Similarly, this musical group carries over Islamic songs as the characteristics of RMC. Beside shalawat and qasidah, the composed songs are adopting the tone of shalawat and qasidah with other lyrics, so called contrafacta -a composition of a new lyric by recycling an old song (Rasmussen, 2019). The example is as follows:

\author{
Thalaal badru alaina \\ Min tsaniyyatil wada'i \\ Wajabasysyukru alaina \\ Mada'a lillahi da'i \\ Duh tarètan sè padhâ moljâ (Dear brothers and sisters) \\ Ngèrèng pakuwwat èlmo akidâh (Let's strengthen our knowledge and faith) \\ Bilâ nyabâ dhâpa' ghân dâdâ(When the death has come) \\ Kasta rajâpon padâ bâdâ(You will very regretful)
}

Besides collaborating the traditional and Islamic music performance, Islamic pop music is also considered. There is no doubt that the emergence of Islamic musical bands, such as Sabyan Gambus, Esbeye (Syubbanul Akhyar), and so on, have a significant influence on the community in determining its music genre.

Another program is a musical performance by those aforementioned groups. The performance becomes a routine agenda within the members or outside the community with the support from other stakeholders and communities. Recently, RMC Musik perform regularly in Koloman Pojok Surau (KPS), a monthly discussion on any topic such as culture, youth, Islam, governance etc. In some cases, the groups of RMC are also invited to many events such as maulid nabi, walimatul ursy, walimatul hajj, walimatul aqiqah and any related events.

This study also found that the members of RMC perceive positively the existence of their community as well as their participation. Many of them said that their involvement in the community has developed their ability to play musical instruments. Moreover, their performance in many events has also helped them earn some money. Undoubtfully, some members are becoming players or vocal coaches in school institution, Islamic boarding school, and other communities.

The above description revealed at least two major topics that are worthy to discuss: the role of RMC community within the society, especially the youth generation, and their role in terms of identity expression. It is interesting to discuss the role of RMC within the societies. Since the 
mission has been clearly stated in the statutes and any related documents, it is not difficult to identify their mission. Moreover, in-depth interviews with the chairs and the members of the community have significantly enriched the data. The research found that RMC community is a place where young talents can explore and express their musical interests in particular. Most of them came to the community with no skills in musical instruments (some are with the competence). They got a significant improvement in their competence in musical instruments due to their involvement in rehearsals and workshops. There is no doubt that having the competence in musical instruments brings benefits to the members of the community. In line with this, RMC community plays their role as the place of 'coming out' in which the members are certainly prepared to be involved in other society. Seemingly, it just occurred recently since some RMC members are ready to actively involve in any music rehearsal as a coach. Also, some members who are undergraduate students can easily join the students association of the campus in line with their talents and interests. Indeed, it is such an amazing achievement for the community.

Interestingly, it is only a slight sample of how RMC members can contribute to other communities. Another role that RMC has been taking is becoming a place for delivering Islamic teachings and values to societies. It is considered as the primary role of RMC in societies. This arose from the idea that getting them engaged in a community, rather than in a classical religious sermon, is a better strategy to affix Islamic values. Delivering Islamic music within a community is a participatory activity performed by and for the community [5]. Indeed, the lyrics of shalawat is religious and the members' participation leads to social interaction. Therefore, the society in general and the members in particular are benefiaries in terms of valuable messages and social interaction.

Another aspect worthy to portray is the identity expression of the youth. It was profoundly delineated on the programs carried out by the community and the music by which RMC Community shows their existence. Firstly, the programs that have been established by the community reflect the mission of RMC, that is maintaining the traditional or local music tradition. It is undeniable that the emergence of globalization in all aspects of life has gradually replaced the position of local traditions in societies. Indeed, the product of globalization like modernization tends to erode the local traditions that have been existing for many decades. Moreover, Islamic tradition is also inherent in this community. It can not be neglected that RMC community is situated in the district in which the Islamic development and movement has been announced, i.e. the so-called Pamekasan Gerbang Salam (Gerakan Pembangunan masyarakat Islami). Indeed, both Islam and local traditions are the primary concern of this community. Besides, various musical instruments, music genres, and songs in use are also worthy to identify. The collaboration of traditional, modern, and Islamic musical instruments produces a various composition which is so melodious and sweet-sounding.

The explanation above reflects the importance of being open and aware of everything that is happening in the society as manifested in the expression of socio-cultural spirits of an organization or a community. RMC community and any religious community should embody this spirits to prevent alienation, cultural shock, and split personality [11]. Therefore, this community helps them negotiate their identities within their society, namely being a religious generation without ignoring their local traditions. In other words, the existence of RMC Community represents their modernity, traditional heritage, and Islamic values. This is in line with Stokes's definition of music cited in Sunardi [12, p. 91] that music is socially meaningful not entirely but largely because [it provides] means by which people recognize identities and places, and the boundaries which separate them. Therefore, it can be said that they express their Islamic and cultural identities as Maduresese and millennials as well.

Most importantly, the finding above also reveals that RMC community delineates the expression of Islamic identity within the youth in a moderate manner. Recently, the concept of moderation (Arabic: wasathiyah) has been widely promoted. Moderation becomes an interesting topic to discuss even it is widely used as the topic of speech among the Indonesia's Islamic leaders. Kamali [13] stated that moderation is an ethical virtue to an exclusively individual, group or community and nation. The concept of musical instruments, music genres, and the songs in use reflects how Islam can be in harmony and synergy with local cultures. The various traditional Islamic music reflects moderation values and tolerance within a faith (Fealy, 2006 as cited in Rasmussen, 2019). 
As mentioned earlier, RMC community has been established in the region in which the sharia regulation is applied. It emphasizes that the presence of RMC strongly stabilized the regulation itself. However, it is not true to say that the presence of Gerbang salam is an attempt to discriminate other religions. Therefore, RMC community within Pamekasan Gerbang Salam is used as a reference or the basis of identity expression as Muslims.

\section{Conclusion}

RMC community has been present and gaining a positive view among the members and the wider society through their significant roles in expressing identity for the youth. The identity expression may lead to two ways. The first is that RMC community attempts to confirm the Muslim and Madurese identities of its members in particular and the society in general. The second is that the community has high respect toward the local music traditions and millenial generation living in the current modern era. To sum up, RMC community is a media where Islamic identity, modernity, and local traditions are combined and brought together to the societies.

\section{References}

[1] M. Thoyibi, Y. Khisbiyah, and A. Ali, Sinergi Agama \& Budaya Lokal (Dialektika Muhammadiyah dan Seni Lokal). Surakarta: Muhammadiyah University Press, 2003.

[2] S. Zainuri, "Seni dalam Perspektif Islam," in Sinergi Agama \& Budaya Lokal, Surakarta: Muhammadiyah University Press, 2003, p. 123.

[3] Q. Shihab, "Islam dan Seni," Muhammad Quraish Shihab Official Website, May-2014. .

[4] Y. Al Qaradhawi, Fiqih Maqashid Syariah: Moderasi Islam Antara Aliran Tekstual dan Liberal (Edisi Indonesia). Jakarta: Pustaka Al-Kautsar, 2007.

[5] A. K. Rasmussen, Merayaan Islam dengan Irama: Perempuan, Seni Tilawah, dan Music Islam di Indonesia. Bandung: Mizan Pustaka, 2019.

[6] E. Hariyanto, "GERBANG SALAM: Telaah atas Pelaksanaanya di Kabupaten Pamekasan,” Karsa J. Soc. Islam. Cult., vol. 15, Mar. 2012.

[7] R. Sekewael, "Indonesian popular music and identity expressions: Issues of class, Islam and gender," Feb-2016. .

[8] D. Ary, L. C. Jacobs, A. Razavieh, and D. Ary, Introduction to research in education, 8th ed. Belmont, CA: Wadsworth, 2010.

[9] J. W. Creswell, Qualitative Inquiry and Research Design: Choosing Among Five Approaches, Third Edition edition. Los Angeles: SAGE Publications, Inc, 2012.

[10] H. Bouvier, Lebur! Seni Musik dan Pertunjukan dalam Masyarakat Madura. Jakarta: Yayasan Obor Indonesia, 2002.

[11] A. P. Bahtiar, "Dialektika Agama dan Budaya; Ketegangan Kreatif untuk Merumuskan Strategi Kebudayaan Muhammadiyah,” in Sinergi Agama dan Budaya Lokal, Surakarta: Muhammadiyah University Press, 2003.

[12] C. Sunardi, "Making Sense and Senses of Locale through Perceptions of Music and Dance in Malang, East Java," Asian Music, vol. 41, pp. 89-126, Dec. 2010.

[13] M. H. Kamali, The Middle Path of Moderation in Islam: The Qur'anic Principle of Wasatiyyah. Oxford University Press, 2015. 